\title{
THE SENATE AND HOUSE COUNSEL OFFICES: DILEMMAS OF REPRESENTING \\ IN COURT THE INSTITUTIONAL CONGRESSIONAL CLIENT
}

\author{
CHARLESTIEFER*
}

\section{INTRODUCTION}

The separation of powers disputes in recent decades involve frequent disagreements over the divergent constitutional interests of the two elected branches of government, the President-led Executive, and the Legislative. ${ }^{1}$ Congress seeks to effectuate its constitutional powers and to check the Executive through legislative devices such as the Independent Counsel statute, the arms sales and war powers laws, and legislative vetoes of statutory or nonstatutory kinds. Congress also conducts high-profile investigations of the Executive, such as the Iran-Contra inquiry and successive Clinton A dministration scandal probes. Presidents fight back by disputing the constitutionality of these legislative devices and by resisting congressional investigations. Conversely, the Executive $B$ ranch investigates and prosecutes $M$ embers of Congress, taking a narrower view of congressional privileges than $M$ embers do.

$M$ any of the disputes take place out of court, in battles over the enactment or vetoing of bills, in dueling opinions on constitutionality, and in invocations and contestations of evidentiary privileges. However, much of the struggle does take place in court. The sharp divergence in the Executive and congressional interests in the struggle presents the Senate and the H ouse of R epresentatives with the problem of how their institutional interests can be represented in court. In the past twenty years, both chambers have developed legal offices, the Senate L egal Counsel and the General Counsel of the H ouse of R epresentatives, to appear in the world of litigation and represent the interests of the ut-

Copyright $\odot 1998$ by L aw \& Contemporary Problems

This essay is also available at http://www.law.duke.edu/journals/61L CPT iefer.

* A ssociate Professor of L aw, U niversity of Baltimore. A ssistant Senate L egal Counsel, 197984; Solicitor and Deputy General Counsel of the House of Representatives, 1984-95; A cting G eneral Counsel of the H ouse of R epresentatives, 1993-94.

The author would like to thank for their review of a draft of this article Stanley M. Brand, Neal D evins, M organ Frankel, K erry K ircher, and $\mathrm{M}$ ort R osenberg. A II views and imprecisions in the article are the author's responsibility, not theirs. A lso thanked are Lori Sherwood for her research assistance, and E mily R. G reenberg and R obert Pool for their skilled library computer assistance.

1. See G eoffrey P. M iller, From Compromise to Confrontation: Separation of Powers in the Reagan Era, 57 GEO. WA SH. L. REV. 401 (1989). 
terly different world of Congress. I had the privilege of serving in both offices, as A ssistant Senate Legal Counsel from 1979-84, and as Solicitor and Deputy General Counsel of the House of R epresentatives from 1984-95. Therefore, I can provide some perspective about how a lawyer on the inside thinks about the dilemmas of representation, particularly the different cultures of the Senate and the House.

This essay looks at two particular clusters of issues regarding institutional representation of Congress. First, Congress uses its institutional counsel when litigating with the President over the constitutionality of statutes. For this, INS v. Chadha, ${ }^{2}$ the Supreme Court case regarding the legislative veto, provides the best example. Second, Congress uses its institutional counsel in different types of controversies, where the presence of distinct partisan or individual interests make it more of an effort for counsel to discern the institutional interest, and particularly difficult for counsel to avoid the perception that the interest being served is the partisan or individual one. For this type of controversy, the 1995 Senate vote to send the Senate L egal Counsel to enforce a W hitewater Committee subpoena for Presidential counsels' notes (the "1995 W hitewater Committee Subpoena" dispute) provides a comparatively recent and dramatic example to analyze.

B ecause the scholarly literature about the evolution and activity of the congressional counsel office lacks the depth of the comparable literature for, say, the Solicitor G eneral's office, I will begin with a discussion about the development of the offices. Then, when going on to Part III's discussion of the Chadha case and similar litigation, and Part IV 's consideration of the 1995 W hite H ouse Subpoena matter and the broad problem of finding institutional interests, I will provide additional examples of the offices' activity, and then attempt a conclusion about the future.

\section{RISE OF THE SENATE AND HOUSE COUNSELS}

Congress statutorily created the Senate L egal Counsel office in the $E$ thics in Government A ct of 1978 (the "1978 A ct"), ${ }^{3}$ in reaction to a need for representation felt in the post-W atergate era. From the office's inception in $1979^{4}$ until 1995, it was headed by M ichael D avidson. ${ }^{5}$ The office inherited a large dispute with the Department of Justice ("DOJ")-over the legislative veto issue and

2. 462 U .S. 919 (1983).

3. R elevant sections are codified at 2 U .S.C. § 288 (1994).

4. For an early description, see Lisa Shively, Senate Legal Counsel D efends Members, Aides, ROLL CALL, O ct. 18, 1979.

5. Davidson's nonpartisan style so satisfied the Senate's requirements that he served 16 years under M ajority Leaders R obert Byrd (D-W. V a.), H oward B aker (R-Tenn.), R obert Dole (R-Kan.), Byrd again, G eorge M itchell ( $D$-M aine), and Dole again, consistently building the office's reputation for being above controversy. 
other smaller disputes over the constitutionality of a series of statutes-because of Executive unwillingness to defend those statutes. ${ }^{6}$

A parallel office had evolved in the H ouse. Speaker Thomas P. O'N eill (D M ass.) had made Stanley M. Brand the House's G eneral Counsel in 1979, with directions to begin representing the House's institutional interest in litigation. ${ }^{7}$ In 1982, Brand's office's significance received general recognition when the A dministration filed the celebrated case of U nited States v. H ouse of Representatives $^{8}$ to resolve the A nne Gorsuch/Superfund executive privilege dispute. Brand won the case, and then left to found his own firm, ${ }^{9}$ leaving Steven $R$. $R$ oss as his successor for the challenging next decade.

Increasingly, both counsel offices defended civil suits, ${ }^{10}$ and provided advice and litigation support for congressional investigations on matters such as privilege invocations ${ }^{11}$ and demands on the investigators for records or testimony. ${ }^{12}$ By the 1990s, the counsel offices faced the diverse additional legal fallout from the newly intense focus upon congressional ethics, on matters ranging from the

6. A helpful description of the office's functions written by M ichael Davidson is, Senate L egal Counsel, in FLOYD M. RIDDICK \& A LAN M. FRUMIN, RIDDICK'S SENATE PROCEDURE, S. DOC. NO. 101-28, at 1236-46 (1992). M. Elizabeth Culbreth, M ajority Leader Baker's selection in 1981 to be Deputy Legal Counsel, established a pattern of nonpartisan trust and effectiveness in the office, successfully concluding the sensitive long-running case about congressional franking practices. See Common Cause v. B olger, 512 F. Supp. 26 (D.D.C. 1980), aff'd, 461 U .S. 911 (1983).

7. At the time, the title was formally Counsel to the Clerk of the House, but with Speaker $O$ 'N eill's backing, the position assumed its broader role, ultimately having its name changed to H ouse General Counsel to match that role. The office at varying times has been administratively independent and a part of the Clerk's system of House support offices, but either way the office has been independent of supervision on legal decisions other than by general reporting to the Speaker and majority and minority leaderships (similar to other $\mathrm{H}$ ouse professional offices such as the Parliamentarian). The rule defining the office's function is currently R ule I.11 of the H ouse of R epresentatives. For an account of the office's initial period, see $D$ avid L auter, O $n$ the Inside: A s C hief $L$ awyer for the H ouse, Stanley B rand I s M aking H is M ark, N A T'L L.J ., M ay 16, 1983, at 1.

8. See 556 F. Supp. 150 (D.D.C. 1983).

9. I then left the Senate office to join the House office. For a profile of R oss's role at that time, see Martin Tolchin, L awyer of the House: A Rising Star, N.Y. TIMES, Oct. 24, 1986, at B6. A Iso helping establish the House office were M ichael L. M urray, the Senior A ssociate Counsel who served from 1980 until 1996 as the expert on H ouse operations, and long-term assistant counsels J anina A . J aruzelski, R. M ichael L ong, and R ichard P. Stanton.

10. See Coalition to End the Permanent Congress v. R unyon, 979 F.2d 219 (D.C. Cir. 1992); M urray v. Buchanan, 720 F.2d 689 (D.C. Cir. 1983) (en banc) (holding that the payment of salaries for chaplains of both the Senate and the House of Representatives did not violate the Establishment Clause of the First A mendment); Susan B. Glasser, Former Challenger to Rep. Chris Smith L oses Franking Case but M ay Go to Supreme Court, R OLL CA LL, J uly 12, 1990 (regarding Rep. Chris Smith $(\mathrm{R}-\mathrm{N} . J)$.$) .$

11. See H arris v. B oard of G overnors, 938 F.2d 720 (7th Cir. 1991); In re H arrisburg G rand J ury, 638 F. Supp. 43 (M.D.Pa. 1986). O ne A ssistant Senate Legal Counsel went on to publish the treatise on the general subject. See JOHN C. GRABOW, CONGRESSIONAL INVESTIGATIONS: LAW AND PRACTICE (1988).

12. See M inpeco v. Conticommodity Services, Inc., 844 F.2d 856 (D.C. Cir. 1988), aff'g M isc. 860110 (D.D.C. J uly 9, 1986); Tavoulareas v. Piro, 527 F. Supp. 676 (D .D.C. 1981); U nited States v. Peoples Temple of the D isciples of Christ, 515 F. Supp. 246 (D .D .C. 1981); cf. Paisley v. CIA, 724 F.2d 201 (D.C. Cir. 1984) (Senate L egal C ounsel appears in F reedom of Information A ct case regarding Senaterelated documents); Peter K iewit Sons' Co. v. U nited States A rmy Corps of E ng'rs, 714 F.2d 163 (D .C. Cir. 1983) (Senate L egal Counsel appears in case regarding Senate committee oversight). 
workings of the House Bank to the allegations against Senator Packwood. ${ }^{13}$ Particularly in the House, insurgent minority party members sometimes challenged the running of the institution by filing lawsuits. ${ }^{14}$

The 1994 election led, eventually, to Senate M ajority L eader D ole ( $R-K$ an.) appointing a new Senate Legal Counsel, Thomas B. G riffith, ${ }^{15}$ and to Speaker N ewt $\mathrm{G}$ ingrich ( $\mathrm{R}-\mathrm{G}$ a.), after a transition period, ${ }^{16}$ appointing a new long-term H ouse $G$ eneral Counsel, G eraldine R. G ennet. ${ }^{17}$

\section{III}

\section{Disputes With the ExeCutive BRAnCh OVER the CONSTITUTIONA Lity OF STATUTES}

The INS v. Chadha ${ }^{18}$ case epitomizes the category of litigation in which the institutional interest is most clear and distinct from partisan or individual interests, namely, litigation between institutional counsel for the Executive B ranch and for Congress over the constitutionality of statutes. The issue in Chadha was the legislative veto, which, in that case, consisted of a statute delegating power to the Executive B ranch to do something, subject to "veto" by a resolution adopted by one or both H ouses of Congress. The statute in Chadha gov-

13. In an earlier era, epitomized by the K oreagate ethics issues and prosecutions of the late 1970s, members' ethics matters had often not required Congressional counsels to do much litigating. The different ethics issues and patterns of the 1980s changed this. For accounts from this period, see Susan B. Glasser, From Cramped Digs, House Counsel D efends Congress in Cases Frivolous and M onumental, RoLL CALL, J an. 20, 1992; Terence M oran, Speaker's Tool or Congress' Champion: House Counsel Feels the Heat, LEGA L TIMES, J une 1, 1992, at 1 ; D avid F. Pike, H is J ob Blends Old with N ew: Senate Counsel Handles O ne Client, 100 Bosses, L.A. DAILY J., Sept. 7, 1994, at 1; Charles Tiefer \& H yde Murray, Congressional Elites Become Take-Charge Managers in New E ra, LEGAL TIMES, Sept. 18, 1989 , at 38.

14. See infra notes 54-57 and accompanying text.

15. $\mathrm{H}$ is replacement was read by some observers to signal a majority party leadership removal of one of the buffers against partisanship in the office, though the signal lay only in that replacement, not in the actual functioning of the office thereafter, which has continued to win respect. See Harvey Berkman, Senate H ires an O utsider as Counsel, NA T'L L.J., M ar. 27, 1995, at A 14; M ary Jacoby, O utgoing Senate L egal Counsel A sked to Stay as D eputy Counsel A fter 16 Y ears in Top J ob, R OLL CALL, M ar. 16, 1995; Eamon Javers, Dole Picks New Senate Counsel to Replace Democrat, THE HILL, Mar. 15, 1995, at 8; D aniel K laidman, Partisan Power Grab?; Senate Counsel Shakeup, LEGA L TIMES, M ar. 13,1995 , at 1 . A n important element of continuity, notwithstanding the replacement of the Senate Legal Counsel, was the choice by the Democratic leadership of Morgan Frankel, who had rendered distinguished service since 1981 as D eputy L egal C ounsel.

16. Two House General Counsels served between 1994, when I ceased being A cting General Counsel but continued as Solicitor, and 1996, when Geraldine R. Gennet started as A cting and then full General Counsel. See Daniel Klaidman, From Hill O utsider to H ouse In-H ouser, LEGAL TIMES, Jan. 16, 1995, at 1 . The office's regular work of responding to private lawsuits and subpoenas continued during the transition, particularly in two cases that I argued: A lbanese v. M olinari, $884 \mathrm{~F}$. Supp. 685 (E.D.N.Y. 1995), and Maddox v. Williams, 855 F. Supp. 406 (D.D.C. 1994), aff'd sub nom., Brown \& Williamson Tobacco Corp. v. Williams, 62 F.3d 408 (D.C. Cir. 1995).

17. It reduced potential controversies about the office itself that the Speaker, in picking $G$ ennet as H ouse G eneral Counsel and K erry K ircher as D eputy G eneral Counsel, had appointed career federal litigators without partisanship in their record.

18. 462 U.S. 919 (1983); see generally BARBARA H. CRAIG, CHADHA: THE STORY OF AN EPIC Constitutional StRuggle (1988); Michael Davidson, Reflections from the Losing Side, REG., J uly/A ug. 1983, at 23. 
erned the deportation of aliens for lack of a legal right to remain in the $U$ nited States. ${ }^{19}$ The statute empowered the A ttorney G eneral to suspend such deportations but also provided that either the House or the Senate could veto the suspension of deportation by enacting a one-chamber "veto" resolution. ${ }^{20}$

Such legislative vetos had a long history. ${ }^{21}$ Particularly since the massive delegations of authority by Congress to the President beginning with the $\mathrm{New}$ D eal and World War II, Congress had sought to cabin the delegations through legislative veto provisions. Presidents had sought the delegations of power, sometimes accepting and sometimes protesting the accompanying legislative vetoes. U Itimately, in the cases of the 1980s regarding an array of statutory devices, the courts drew a formalist line invalidating some types of provisions, but allowing other types to stand.

The decisive round of litigation began when opponents of the legislative veto got one deportable alien, Jagdish $\mathrm{R}$ ai Chadha, to bring a test case. The Senate and House each had counsel present the case to the Supreme Court in briefing and argument. I drafted the Senate's main brief. ${ }^{22}$

The case, and the other litigation over the legislative veto, support several conclusions regarding the role of congressional counsel in this category of litigation. First, the legislative veto litigation illustrates how, in such relatively less partisan matters, Members of Congress allow congressional counsel to represent the readily discernible institutional interest. ${ }^{23}$ On the presidential side, Presidents from Franklin R oosevelt to Carter and Bush sought authority that came only with some type of legislative veto arrangement. The Presidents considered, but repeatedly overruled, the legally grounded protests against legislative veto arrangements expressed by their A ttorneys $G$ eneral or, in B ush's case, White House Counsel C. B oyden Gray. While the presidents had their way in accepting legislative veto arrangements, DOJ had its own way in litigation, starting with the Chadha case in the (Democratic) Carter A dministration and continuing in the (Republican) Reagan A dministration. ${ }^{24}$ In other words, the

19. See 8 U .S.C. $\S 1254$ (1994).

20. See Chada, 462 U .S. at 924.

21. For a discussion of the legislative veto, see LOUIS FISHER \& NEAL DEVINS, POLITICAL DYNAMICS OF CONSTITUTIONAL LAW 121-27 (1992); for a series of documents regarding disputes arising during that history, see id. at 131-38.

22. Supplemental Brief on Reargument of the U nited States Senate, A ppellee-Petitioner, INS v. Chada, 462 U .S. 919 (1983) (N o. 80-1832). The Court set the case for rebriefing and reargument. I did not draft the initial Senate brief, which focused on jurisdictional and other threshold defenses, but I did draft the Senate brief on reargument, which presented an extensive history of the legislative veto. A Ithough Congress lost, I had the satisfaction that Justice White's dissenting opinion in the case reprinted verbatim some very extensive parts from the brief.

23. See Stanley M. Brand, B attle A mong the Branches: The Two Hundred Y ear War, 65 N.C. L. REV. 901 (1987); Steven R oss, The Role of the L egislative and Executive Branches in Interpreting the Constitution, 73 CORNELL L. REV. 383 (1988).

24. The well-known examples of presidential acceptance of legislative vetos included President Bush overruling B oyden $\mathrm{G}$ ray about the informal committee veto arrangement for funding of Nicaraguan Contras, see FISHER \& DEVINS, supra note 21, at 141-42, and President Carter making A ttorney General Griffin Bell write an opinion defending, as constitutional, the legislative veto for the R eorganization A ct authority that Carter prized, see id. at 136. For treatments of the issues, see Christo- 
Executive Branch separated the process of making legislation and arrangements with Congress, where it did not have a particular consistent institutional position against legislative vetoes, from the process of litigation, where it did.

Similarly, in Congress, enacting or arranging legislative vetoes appealed to conservative R epublicans and appalled progressive Democrats, or vice-versa, depending on the particular statutory context. ${ }^{25}$ M embers of Congress wished to make up their own minds, by whatever mix of policy, legal, and other factors, about whether to enact or to establish otherwise various legislative veto arrangements, and whether, after their establishment, to trigger them regarding particular Executive actions. ${ }^{26}$ However, Members of Congress, as did Presidents, seemed willing, once litigation began, to let the matter be handled by their institutional litigation counsel. Members simply accepted that if the Executive Branch let its lawyers, on an institutional basis, seek judicial decisions invalidating a type of legislation, they should let their lawyers respond. It was appropriate for the issue to be left to institutional counsel to view in a longterm, institutional way, for two reasons. First, individual members recognized that their interests were too lightly engaged on the issue compared to the collective interest of the Senate and House. Second, party mechanisms that articulate collective interests in ways that divide the legislative institution also did not engage on the issue. DOJ's litigative stance did not involve any partisan component, as it first weighed-in during the Carter A dministration, when the same party controlled both branches, and continued unchanged into the R eagan A dministration, serenely ignoring the changes in party fortune in the 1980 election. DOJ's nonpartisanship induced legislative nonpartisanship. The issue consistently seemed institutional, not partisan. Thus, our challenge as congressional counsel was not in discerning or securing agreement about the overall institutional interest. The same vague notions by which the Executive B ranch let D OJ "attack" the legislative veto, similarly caused the Legislative B ranch to let congressional counsel "defend" it.

pher N. May, Presidential D efiance of "Unconstitutional" L aws: Reviving the Royal Prerogative, 21 H A STINGS CONST. L.Q. 865 (1994); A rthur S. M iller \& J effrey H. B owman, Presidential A ttacks on the Constitutionality of Federal Statutes: A N ew Separation of Powers Problem, 40 O HIO ST. L.J. 51 (1979); Note, Executive D iscretion and the Congressional D efense of Statutes, 92 Y A LE L.J . 970 (1983); Eva R. R ubin, Congress v. the President in Court: Congressional Legal Offices, the D efense of the Constitutionality of Statutes and the Separation of Powers (paper delivered at the Southwestern Social Science A ss'n, D allas, Texas, M ar. 18-21, 1987) (on file with author).

25. For example, conservative members approved legislative vetoes regarding regulatory rulemaking, while progressive members approved the legislative veto in the War Powers R esolution, 50 U .S.C. §§ 1541-1548 (1994).

26. For expert nonpartisan advice on such matters during the legislating process, members' primary resource consists of the specialists in the Congressional Research Service's A merican L aw D ivision, such as M ort R osenberg, or in the Government Division, such as L ouis Fisher, rather than the litigators in the congressional counsels' offices. See, e.g., MORTON ROSENBERG, CONGRESSIONAL RESEARCH SERV., INVESTIGATIVE OVERSIGHT: A N INTRODUCTION TO THE LAW, PRACTICE AND PROCEDURE OF CONGRESSIONAL INQUIRY (1995); Louis Fisher, Constitutional Interpretation by Members of Congress, 63 N.C. L. REV. 707 (1985); M uriel M. Spence, What Congress Knows and Sometimes Doesn't K now, 30 U . RICH . L. REV. 653 (1996). 
$\mathrm{R}$ ather, our challenge was implementing a long-term view for the widely varying legislative vetoes facing challenges in successive constitutional cases. To be sure, for all the lawsuits, we had overall formalistic and functionalist themes: formalistically, that each statute containing a legislative veto had received bicameral approval and presentment (albeit that veto resolutions did not), and functionally, that the legislative veto device existed to confine delegations of authority. However, implementing a long-term view involved much more than merely repeating those overall arguments. In each of the widely varying statutory settings, from the immigration and regulatory laws to the appropriation and procurement laws, the long-term view was to differentiate the legislative veto statutes and to elucidate their origins and roles in checking delegated authority in different statutory settings. ${ }^{27}$

Implicit in that strategy was our conclusion that Congress's institutional interest lay in achieving a judicial standard that dealt with each statute on a particularized basis. We knew the judicial hostility to some legislative vetoes. ${ }^{28}$ We knew, from discussions and observations with members and staff, the great importance of the diverse web of congressional review arrangements from conditional nonstatutory "report-and-wait" arrangements to the War Powers R esolution's provision for bicameral resolutions ending U S. military involvement in hostilities. Given that knowledge, and the freedom of action that Congress gave its institutional counsel on this issue for the previously described reasons, we defined the institutional interest as preserving as much of that web of congressional arrangements as could survive a succession of cases.

With this long-term approach to defining and defending the legislative interest, the Chadha decision, al beit a major defeat for us, by no means ended the whole subject. Following Chadha in 1983, A ttorney General Edwin M eese's main Chadha-based thrust consisted of his assertive declaration that the Competition in Contracting A ct of $1984,{ }^{29}$ with its legislative provision that stayed procurements pending a form of legislative review, was unconstitutional and should not be obeyed by the Executive Branch. ${ }^{30}$ Congress succeeded early in forcing the withdrawal of M eese's declaration of unconstitutionality, and succeeded ultimately in completely defending that provision, winning decisions

27. See, e.g., City of A lexandria v. U nited States, 737 F.2d 1022 (Fed. Cir. 1984); Consumer E nergy Council of A m. v. Federal E nergy R egulatory Comm'n, 673 F.2d 425 (D.C. Cir. 1982); A merican Fed'n of G ov't E mployees v. Pierce, 697 F.2d 303 (D.C. Cir. 1982); National Wildlife Fed'n v. Clark, 577 F. Supp. 825 (D.D.C. 1984); Pacific L egal Found. v. W att, 529 F. Supp. 982 (D. M ont. 1981).

28. We had more information about judicial hostility to legislative vetoes than did almost anyone else in Congress, since we knew from oral arguments the thinking of many judges who did not write opinions on the merits in our cases. For example, I argued one legislative veto case before the D.C. Circuit en banc prior to Chadha, with relentlessly hostile signals from the bench. See Consumers U nion of U.S., Inc. v. FTC, 691 F.2d 575 (D.C. Cir. 1982) (en banc) (per curiam) (holding that a requirement that the FTC submit its rules to Congress for review violated separation of power principles by effectively giving Congress veto power).

29. See 31 U .S.C. § 3551 (1994).

30. See A meron, Inc. v. U nited States A rmy Corps of E ng'rs, 610 F. Supp. 750 (D.N.J . 1985). 
upholding the statute in both circuit courts that heard cases. ${ }^{31}$ These victories for the legislative interest followed from defining the litigation approach as differentiating the diverse statutory contexts-specifically, for the 1984 A ct cases, the particular setting of the Act's aim of curbing waste and abuse in defense procurement, and the particular mechanism of a limited stay (not "veto") of procurement decisions. ${ }^{32}$ Thereafter, with Chadha's limits established, variants of the legislative veto device, particularly nonstatutory ones, flourished. ${ }^{33}$

The challenge of defending the congressional interest on issues of statutory constitutionality went well beyond the core of head-on clashes like Chadha. ${ }^{34}$ D OJ claimed other powers in this context, such as refusing to defend a statute when it deemed the arguments for the statute's constitutionality unreasonable. ${ }^{35}$ In the 1980s, congressional counsel defended the Gramm-R udman deficit control act, ${ }^{36}$ the Independent Counsel statute, ${ }^{37}$ a pocket-vetoed bill, and others. ${ }^{38}$ D uring the Clinton A dministration, the Senate and $\mathrm{H}$ ouse counsel offices have presented defenses of the line item veto ${ }^{39}$ and of the qui tam provisions of the

31. See L ear Siegler, I nc. v. L ehman, 842 F.2d 1102 (9th Cir. 1988); A meron, Inc. v. U nited States A rmy Corps of Eng'rs, 787 F.2d 875 \& 809 F.2d 979 (3d Cir. 1986), aff'g 607 F. Supp. $962 \& 610$ F. Supp. 750 (D.N.J . 1985).

32. There was a phase when A ttorney G eneral Edwin M eese claimed the power to issue government-wide orders not to obey statutes, though congressional counsel, working with oversight committees and public opinion, successfully fought back against that assertion. See $L$ ear Siegler, $842 \mathrm{~F} .2 \mathrm{~d}$ at 1102; A meron, 787 F.2d at 875. For background, see PETER M. SHANE \& HAROLD H. BRUFF, SEPARATION OF POWERSLAW: CA SESAND MATERIALS 542-43 (1996).

33. See FISHER \& DEVINS, supra note 21, at 128-30; for documentary examples, see id. at 138-42.

34. Numerous cases arose, such as the 1993 suit over First Lady Hillary Clinton chairing the $\mathrm{H}$ ealth Care Task F orce, in which D OJ 's broad views of Executive powers (in that case, by questioning the constitutionality of the Federal A dvisory Committee Act if applied) posed an issue warranting congressional counsel participation. See A ssociation of A m. Physicians \& Surgeons v. Clinton, 997 F.2d 898 (D.C. Cir. 1993). O ther examples included appropriation riders barring Executive nondisclosure agreements, see A merican Foreign Serv. A ss'n v. G arfinkel, 490 U .S. 153 (1989), and the power to legislate regarding foreign affairs, see J apan Whaling A ss'n v. A merican Cetacean Soc'y, 478 U .S. 221 (1986).

35. Hence, Congressional counsel have defended statutes that DOJ declined-in the absence of any particular Executive Branch prerogative at issue-regarding advertised alcohol content of beer, see Adolph Coors Co. v. Brady, 944 F.2d 1543 (10th Cir. 1991); newspaper broadcast cross ownership rules, see News A m. Pub. Inc. v. FCC, 844 F.2d 800 (D.C. Cir. 1988); and restrictions on candidate endorsements by public broadcasters, see L eague of Women Voters V. FCC, 489 F. Supp. 517 (C.D. Cal. 1980), appeal dismissed, 468 U.S. 1205 (1984). D uring the appeal of this case, D OJ changed its position and took up the statute's defense in the ensuing litigation, which ended in the Supreme Court.

36. See Bowsher v. Synar, 478 U.S. 714 (1986), aff'g Synar v. U nited States, 626 F. Supp. 1374 (D.D.C. 1986). For background, see FISHER \& DEVINS, supra note 21, at 143-45.

37. See M orrison v. O Ison, 487 U.S. 654 (1988); In re Sealed Case, 838 F.2d 476 (D.C. Cir. 1988); North v. Walsh, 656 F. Supp. 414 (D.D.C. 1987).

38. For the pocket veto case, see Burke v. Barnes, 479 U .S. 361 (1987), vacating as moot, Barnes V. K line, 759 F.2d 21 (D.C. Cir. 1985). For other cases, see, for example, M istretta v. U nited States, 488 U.S. 361 (1989) (upholding sentencing guidelines as constitutional); In re Benny, 812 F.2d 1133 (9th Cir. 1986) (holding that Congress could prospectively extend bankruptcy judges' terms of office under the 1984 B ankruptcy A ct without violating the appointments clause); I n re K oerner, $800 \mathrm{~F} .2 \mathrm{~d} 1358$ (5th Cir. 1986) (same); compare M oore v. U.S. H ouse of Representatives, 733 F.2d 946 (D .C. Cir. 1984) (tax statute challenged under the Origination Clause; Congressional counsel appear in defense of Congressional defendants).

39. See R aines v. Byrd, 117 S. Ct. 2312 (1997). 
False Claims A ct, ${ }^{40}$ with every prospect for further statutory defense cases. ${ }^{41}$ 0 ther disputes concern constitutional issues regarding various other congressional processes from trial of judicial impeachments ${ }^{42}$ to Senate confirmation authority infringed by presidential recess appointments. ${ }^{43} \mathrm{E}$ ach of these controversies could have its own case study. ${ }^{44}$ The bottom line would generally be that where the Executive B ranch has an institutional opposition to Congress's powers without particular partisan overtones, the Congress therefore faces the question of defending without particular partisan overtones. W ith partisanship muted, the challenge in these cases for congressional counsel tends less to be discerning an institutional interest, than professionally defining that defense in a way that protects the institution's long-term as well as short-term interest.

40. See U nited States ex rel. K elly v. B oeing Co., 9 F.3d 743 (9th Cir. 1993), cert. denied, 510 U .S. 1140 (1994); U nited States ex rel. K reindler \& K reindler v. U nited Technologies Corp., 985 F.2d 1148 (2d Cir. 1993). In neither line item veto nor qui tam cases did D OJ refuse to defend the statute, but it is thought, on solid grounds, that the congressional counsels had much to add.

41. For examples of recent constitutional rider controversies, see A merican Foreign Serv. A ss'n v. Garfinkel, 490 U .S. 153 (1989); News A m. Pub. Co. v. FCC, 844 F.2d 800 (D.C. Cir. 1988); Clarke v. United States, 915 F.2d 699 (D.C. Cir. 1990). For a discussion, see ChARLES TIEFER, The SemISovereign Presidency: The Bush Administration Strategy for Governing Without CONGRESS 44-50 (1994); N eal E. D evins, Regulation of G overnment A gencies Through L imitation Riders, 1987 D UKE L.J. 456; Peter Raven-Hansen \& William C. Banks, Pulling the Purse Strings of the Commander in Chief, 80 V A . L. REV. 833 (1994).

42. See, e.g., Nixon v. U nited States, 506 U .S. 224 (1993); H astings v. U nited States Senate, 887 F.2d 332 (D.C. Cir. 1989); H astings v. U nited States, 802 F. Supp. 490 (D .D .C. 1992), vacated, 988 F.2d 1280 (D.C. Cir. 1993). For an unsuccessful challenge to Senate cloture rules, see Page v. D ole, N o. 945292, 1996 W L 310132 (D.D.C. M ay 13, 1996); J im O'Connell, Former Congressional Candidate Sues Senate over Constitutionality of Rules on Filibuster, R O LL CA LL, O ct. 14, 1993.

43. See M ackie v. Clinton, 827 F. Supp. 56 (D.D.C. 1993); Neal D evins, Tempest in an Envelope: Reflections on the Bush White House's Failed Takeover of the U.S. Postal Service, 41 U CLA L. REV. 1035 (1994). U nlike other disputes over constitutional issues handled by the Senate L egal Counsel, for this one Senator O rrin $\mathrm{H}$ atch ( $\mathrm{R}-\mathrm{U}$ tah) blocked the Senate L egal Counsel from filing a draft amicus brief. See $M$ ary J acoby, $H$ atch M ove Prevents D emocrats from Filing B rief on $L$ awsuit over Recess A ppointments, R OLL CA LL, J uly 15, 1993; Bill M CA Ilister, Recess A ppointments: A D isputed M atter of Timing, W A SH. POST, J uly 19, 1993, at A 13. M ajority L eader M itchell just placed the draft brief in the Congressional Record. See 139 CONG. REC. S8544 (daily ed. J uly 1, 1993).

44. For example, immediately after enactment of the Flag Protection A ct of 1989, 18 U .S.C. § 700 (1994), its official defense in its initial court tests had to come from Congressional counsel. See U nited States v. E ichman, 731 F. Supp. 1123 (D.D.C. 1990); U nited States v. H aggerty, 731 F. Supp. 415 (W.D. Wash. 1990). (A t the later stages, rather than yield this important task to congressional counsel when the cases went up to the Supreme Court, Solicitor G eneral K enneth W. Starr took up, and devoted himself constructively to, the task of providing the A ct's official defense. See U nited States v. Eichman, 496 U .S. 310 (1990)). A t the start of those flag-burning cases, my challenge did not consist in discerning the congressional interest in upholding the statute, but rather in developing arguments supplementing the record of hearings, reports, and floor speeches.

Some academic observers opine that the matter is one that proves why, once the Supreme Court speaks, Congress's role should be to just obey. See L arry A lexander \& Frederick Schauer, On Extrajudicial Constitutional Interpretation, 110 HARV. L. REV. 1359 (1997). A t the time, Congress, reading the 5-4 Supreme Court decision on flag-burning, with its allusion to J ustice B lackmun's ambivalence, and taking supporting testimony from Professors Tribe and D ellinger, considered it sound to seek $a$ statutory solution rather than rushing to President Bush's proposal for a constitutional amendment. For accounts of the flag matter, see Troy G. Pieper, Playing with Fire: The Proposed Flag Burning A mendment and the Perennial A ttack on Freedom of Speech, 11 ST. J OHN'S J. LEGAL COMMENT 843 (1996); Charles Tiefer, The Flag-Burning Controversy of 1989-90: Congress' Valid Role in Constitutional Dialogue, 29 HARV. J . ON LEGIS. 357 (1992). 
IV

\section{REPRESENTING AN INSTITUTIONA L INTEREST IN CONTEXTSOF PARTISAN AND INDIVIDUAL INTERESTS}

Chadha and related cases concerned a context with relatively less partisanship. Quite different concerns, amounting to difficult dilemmas, arise for the congressional counsel offices in contexts of strong partisan or individual interests. The 1995 Whitewater Committee Subpoena matter provides a useful starting point for discussing this problem.

When the 1978 Ethics in Government A ct established the Senate Legal Counsel's office, it also established a civil enforcement mechanism for Senate committee subpoenas. ${ }^{45}$ If a witness refused to obey the subpoena of a Senate committee, and the committee reported the matter to the full Senate, the Senate could vote on whether to enforce the subpoena. ${ }^{46}$ This provision fits in with a general pattern, in which both the Senate and House counsel offices advise investigating committees. ${ }^{47}$ In the initial cases of Senate subpoena enforcement, the Senate approved the enforcement action by unanimous consent. Then, in the dramatic Packwood case, floor disputes occurred before the Senate authorized subpoena enforcement. ${ }^{48}$

In late 1995, the Senate Whitewater Committee invoked this statutory mechanism to demand notes of a W hitewater meeting of the President's private and White House attorneys. ${ }^{49}$ The White House invoked attorney-client privilege. Legal contests regarding privilege between the White House and the Senate rarely go as far as this one did. The Senate W hitewater Committee split sharply on party lines, the Senate voted along party lines regarding whether to

45. See 2 U .S.C. § 288b (1994).

46. By tradition, the committee's report of the matter to the Senate floor reflects close coordination with the Senate L egal Counsel regarding structuring of the anticipated court case. A Senate vote in favor of enforcement would direct the Senate Legal Counsel to file a subpoena-enforcement action in federal district court; the witness would have to obey a judicial order enforcing the subpoena on pain of contempt of court. For some examples, see M atter of the A pplication of the United States Senate Permanent Subcomm. on Investigation, 655 F.2d 1232 (D.C. Cir. 1981); Senate Select Comm. v. Secord, 664 F. Supp. 562 (D.D.C. 1987).

47. For example, in the late 1980s, both counsels dealt with the major legal demands of the I ranContra investigations. A mong other aspects, the House office detailed me to serve as Special Deputy Chief Counsel of the H ouse Iran-Contra Committee. See generally G eorge W. Van Cleve \& Charles Tiefer, Navigating the Shoals of "Use" I mmunity and Secret I nternational E nterprises in Major Congressional I nvestigations: L essons of the Iran-Contra A ffair, 55 M O. L. REV. 43 (1990).

48. The Senate E thics Committee evaluating the allegations against the Senator needed to enforce its subpoena for his diary. A number of Senators opposed the enforcement action for the subpoena, so only after floor debate and a divided roll-call vote did the Senate authorize the Senate L egal Counsel to pursue the ultimately successful subpoena enforcement action. See Senate Select Comm. on Ethics v. Packwood, 845 F. Supp. 17 (D.D.C.), emergency motion for stay pending appeal denied, N o. 94-5023 (D.C. Cir. Feb. 18, 1994), application for stay denied, 510 U .S. 1319 (1994).

49. For accounts of this matter, see LOUIS FISHER, CONSTITUTIONAL CONFLICTS BETWEen CONGRESS AND THE PRESIDENT 166-67 (4th ed. 1997); Mark Miller, A Privileged Character? The President and J oint D efense, 85 GE O. L.J. 1979 (1997); Charles Tiefer, Privilege Pushover: L aw and Practical R ealities Fatally Weakened the President's A bility to A ssert an A ttorney-Client Privilege in the Senate Whitewater Committee, LEGA L TIM ES, J an. 1, 1996, at 24. 
authorize enforcement, ${ }^{50}$ and the White $\mathrm{H}$ ouse surrendered the notes on the eve of suit.

This matter reflects the type of work about which the majority and minority parties dispute what the congressional counsels should do. The dispute raises a question about whether there is an institutional interest at all. ${ }^{51}$ The answer to that question is twofold. First, Congress's procedures allow many nuances in just how partisan a decision is. The Senate minority opposed the 1995 Whitewater notes enforcement vote, but it did not filibuster, and it gave no audible objection to the legitimacy of the outcome, both steps that would likely occur if the majority party sought Senate enforcement of an unfair subpoena to, say, the National Organization of Women. Second, as described in the previous discussion of Chadha, the Members' vote during enactment of a measure and the role of the Senate Legal Counsel after enactment can differ. U nder some circumstances, even after a party-line vote adopts something, defending or, for subpoena enforcement resolutions, implementing that vote can occur in a way detached from the partisan decision to adopt.

For something like the Whitewater Subpoena matter, the Senate Legal Counsel would succeed in following-up a partisan vote and by carefully sorting out and discarding the partisan arguments made for enforcing the subpoena and by adopting and developing the institutional arguments in litigation. ${ }^{52}$ The partisan arguments to be discarded are the accusations against the President and his staff about which partisan supporters and opponents sharply disagree; that they do not deserve attorney-client privilege because they assertedly discussed committing violations of law. The institutional arguments to be developed are, for example, why even guiltless Executive officials would not be able in this particular context to deny the notes of their discussions to an authorized congressional investigation. The Senate's institutional position would be the privilege's inapplicability in this context: The President had chosen not to in-

50. 141 CONG. REC. S18993 (daily ed. D ec. 20, 1995).

51. That 1995 vote reflected a basic political judgment-the majority party demonstrating opposition to and the minority party demonstrating support of-the White House in that situation. Skeptics may well argue that, at such points, no "institutional" interest exists at all, only the interest of each party. The outcome consists of one party or the other obtaining the use of the institution's authority not some epiphany of a pre-existing institutional interest. Of course, there are parallels to whether, in other action contexts, there is a "public interest" or a "legislative intent," as opposed to clashing particular interests that win the government or legislative action they seek. I have recently discussed some of the applications of positive political theory and public choice theory to this context. See Charles Tiefer, Congressional O versight of the Clinton A dministration and Congressional Procedure, 50 A DMIN. L. REV. 199 (1998); Charles Tiefer, "B udgetized" H ealth Entitlements and the Fiscal Constitution in Congress's 1995-1996 Budget Battle, 33 H A R V. J. O N L E GIS. 411, 420-25 (1996).

52. In the majority and minority portions of the $W$ hitewater notes committee report, the legally sophisticated treatment of the opposing arguments about privilege in the matter anticipates the issues in court. See The Special Committee to investigate Whitewater Development Cor-

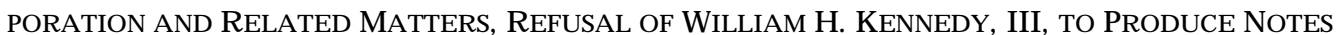
Subpoenaed by the Special Committee to Investigate Whitewater Development Corporation and Related MatTers, S. Rep. No. 104-191 (1995). As A ssistant Senate Legal Counsel, I helped draft the committee reports for two such enforcement actions. The charter for the Senate Legal Counsel's office specifies the particular contents for such a report. See 2 U.S.C. § 288d(c) (1994). 
voke executive privilege formally and the attorney-client privilege arguably could not be raised, at a sufficiently strong level to block a Senate subpoena, absent such a formal Presidential invocation. ${ }^{53}$

Other examples of partisan disputes over the congressional counsels' assignments further illustrate what the 1995 Senate example suggests. From time to time in the House, minority members challenge the running of the chamber in the form either of lawsuits ${ }^{54}$ or of raising questions about the $\mathrm{H}$ ouse $\mathrm{G}$ eneral Counsel's positions regarding outside lawsuits ${ }^{55}$ or D OJ subpoenas. ${ }^{56}$ Since the 1995 transition in party control, the General Counsel has been involved in representation in the course of various minority party challenges. The minority party challenged the new $\mathrm{H}$ ouse rule requiring a three-fifths supermajority vote for tax increases. In response, the $\mathrm{H}$ ouse $\mathrm{G}$ eneral Counsel defended the rule, winning in court. In 1997, the minority party M ember who had won a disputed

53. For example, the majority party, if it were presenting a naked partisan preference, might argue the inapplicability of the attorney-client privilege for meetings at which the participating President's lawyers plan a crime; in contrast, the Senate Legal Counsel would be expected to take a more institutional position, arguing the unavailability of an attorney-client privilege when the President does not invoke executive privilege, deeming Presidential invocation a prerequisite of any assertion of a Presidential privilege. For background on such evidentiary disputes, see Stanley M. Brand \& Sean Connelly, Constitutional Confrontation: Preserving a Prompt and O rderly M eans by Which Congress $M$ ay Enforce Investigative D emands A gainst Executive Branch O fficials, 36 C A TH. U. L. REV. 71 (1986); Neal D evins, Congressional-Executive Information A ccess D isputes: A M odest Proposal-D o Nothing, 48 A D M IN. L. REV. 109 (1996).

54. These included various challenges to congressional pay increases, see B oehner v. A nderson, 30 F.2d 156 (D.C. Cir. 1994); H umphrey v. Baker, 848 F.2d 211 (D.C. Cir.), aff'g 665 F. Supp. 23 (D.D.C. 1987), cert. denied, 488 U.S. 966 (1988), voting by H ouse territorial delegates, see M ichel v. A nderson, 14 F.3d 623 (D.C. Cir. 1994), aff'g 817 F. Supp. 126 (D.D.C. 1993), an election dispute, see M cl ntyre v. O'N eill, 603 F. Supp. 1053 (D.D.C. 1985), the Congressional Record's practices regarding revising and editing, see G regg v. Barrett, 771 F.2d 539 (D.C. Cir. 1985), and committee ratios, see Vander Jagt v. O 'N eill, 699 F.2d 1166 (D.C. Cir. 1983).

55. This period is described in R ebecca M. Salokar, L egal Counsel for Congress: Protecting Institutional Interests, 20 CONGRESS \& PRESIDENCY 131, 149-50 (1993). One example concerned term limits litigation. See Susan B. G lasser, Cox Fails in M ove A gainst Counsel's T erm-L imit B rief, R OLL CA LL, N ov. 7, 1991. R egarding the related litigation, see A dvisory O pinion to the A ttorney G eneralL imited Political Terms in Certain Elective Offices, 592 So. 2 d 225 (Fla. 1991); Susan B. Glasser, Fla. Court R ejects B rief of House Counsel, OK s Term-L imit Initiative for Nov. 3 Ballot, R OLL CA LL, J an. 6, 1992. Regarding other term limits litigation, see 139 CONG. REC. S1146 (daily ed. Feb. 3, 1993) (Senate Legal Counsel authorization); Susan B. G lasser, M itchell Outlines the Senate Objections to States Restricting Terms of M embers: Senate L egal C ounsel A uthorized to Represent Pryor, Bumpers in Term-L imit L awsuit, RoLL CALL, Feb. 8, 1993; Susan B. Glasser, Foley to Sue to Try to Kill Term L imits, R OLL CA LL, M ay 27, 1993. The issue was resolved in U.S. Term L imits, Inc. v. Thornton, 514 U.S. 779 (1995) (holding that states may not impose qualifications for congressional office in addition to the requirements set forth in the Constitution).

56. In 1992, the House voted as a body to turn over the records of every House M ember's checks at the House Bank, precluding the $\mathrm{H}$ ouse $\mathrm{G}$ eneral Counsel from taking a position in court that the subpoena was overbroad on basic separation of powers grounds. The records went to an election-year inquiry staged for maximum political advantage by the Bush A dministration, forgoing the opportunity to ask the courts to narrow the subpoena to records with relevance to the inquiry. See Timothy J. Burger \& Susan B. Glasser, Solemn Hour for the House: Precedent, Privacy Rights Focus of Vote on Wilkey's Subpoena, R o L L CA LL, A pr. 30, 1992; Timothy J. Burger, Wilkey Ends Bank Probe, Tags No M ore Than Four M embers for Criminal Scrutiny, R OLL CA LL, D ec. 17, 1992. Similarly, during this period the $\mathrm{H}$ ouse did not take any amicus role on the political question challenge by R epresentative $D$ an R ostenkowski (D-III.) to his indictment, even though the D.C. Circuit's favorable ruling on that challenge, see U nited States v. R ostenkowski, 59 F.3d 1291 (D.C. Cir. 1995), showed its significance. 
House election found herself the target, during the ensuing election contest, of a subpoena statute wielded by the majority party. She challenged the statute, the $\mathrm{H}$ ouse $\mathrm{G}$ eneral Counsel defended it, and the court upheld the statute. ${ }^{57}$

Besides these types of cases, another complex dilemma for congressional counsel arises in the context of strong individual interests, namely, the cases of individual members in trouble or who have evidence about others. ${ }^{58}$ For example, the counsel offices may provide representation regarding the Speech or D ebate Clause, ${ }^{59}$ the bedrock constitutional protection of the Senate and H ouse against outside legal interference in cases of members prosecuted, ${ }^{60}$ civilly sued, ${ }^{61}$ or subjected to evidentiary demands. ${ }^{62}$

This dilemma elicits a variety of responses. For example, because the traditional Senate and House counsels' approaches to criminal matters diverge somewhat, the House General Counsel's office has more readily stepped forward to represent institutional interests in criminal investigations or cases in a

57. The case concerning the three-fifths supermajority requirement was Skaggs v. Carle, $110 \mathrm{~F} .3 \mathrm{~d}$ 831 (D.C. Cir. 1997) (filed by Rep. David Skaggs (D-Colo.)), aff'g 898 F. Supp. 1 (1995). The case concerning the contested election subpoena statute was D ornan v. Sanchez, 978 F. Supp. 1315 (C.D. Cal. 1997) (filed by Rep. Loretta Sanchez (D-Cal.)). See Rachel Van Dongen, D ornan Subpoenas Face Constitutional Test, R OLL CA LL, Sept. 1, 1997.

58. See Congressional "L aw Firms" Help Out Members in Court, 43 CONG. Q. WKLY. REP. 55 (1986), and cases cited in preceding footnotes. The congressional backing of invocations of Speech or D ebate privilege particularly include $M$ embers seeking to invoke privilege regarding the broad surrounding circumstances of E thics Committee proceedings. Congress has a strong institutional interest in protecting the Members involved in the intense political controversies surrounding those proceedings from distracting and intrusive judicial processes. M embers who seek advice from, or give testimony to, the Ethics Committee would otherwise face later outside subpoenas and questioning. See U nited States v. M CD ade, N o. 96-1508 (3d C ir. J uly 12, 1996) (unpublished order), vacating Cr. N o. 92249 (E.D. Pa. J une 5, 1996); U nited States v. R ose, 28 F.3d 181 (D.C. Cir. 1994); U nited States v. H ansen, 772 F.2d 940 (D.C. Cir. 1985).

59. U.S. CONST., art. I, § 6, cl. 1 .

60. The statutory charter for the Senate Legal Counsel's office limits its representation of members, officers, and staff as parties to civil cases. See 2 U .S.C. § 288c (1994). E ither congressional counsel office may appear in criminal matters by representing document custodians and staff witnesses, or by representing the institution or its leadership as amici. See Helstoski v. M eanor, 442 U .S. 500 (1979); U nited States v. Helstoski, 442 U .S. 477 (1979), on remand, 635 F.2d 200 (3d Cir. 1980); U nited States v. Swindall, 971 F.2d 1531 (11th Cir. 1992); U nited States v. Biaggi, 853 F.2d 89 (2d Cir. 1988); U nited States v. M CD ade, 28 F.3d 283 (3d Cir. 1994), aff'g 827 F. Supp. 1153 (E.D. Pa. 1993), cert. denied, 514 U.S. 1003 (1995).

61. These include suits for defamation, see Hutchinson v. Proxmire, 443 U.S. 111 (1979); Williams v. Brooks, 996 F.2d 728 (5th Cir. 1993); Chastain v. Sundquist, 833 F.2d 311 (D.C. Cir. 1987), employment termination (where they still retain a function although both the Senate and House have now established specific offices, separate from the Senate and H ouse counsels' offices, to handle employment discrimination proceedings), see Juliet Eilperin, A ppeals Court Rejects Capitol Police Challenge to $M$ andatory Retirement, ROLL CALL, A ug. 3, 1995, at 12, and other torts, see Brownsville G olden A ge N ursing Home, Inc. v. Wells, 839 F.2d 155 (3d Cir. 1988); Karchin v. M etzenbaum, 587 F. Supp. 563 (N.D. Ohio 1983).

62. See M ary J acoby, H ill Press Releases Protected Speech, R OLL CA LL, Sept. 7, 1995, at 17; In re City of EI Paso, Texas, 887 F.2d 1103 (D.C. Cir. 1989); Pittston Coal Group, Inc. v. U nited Mine Workers of A merica, 894 F. Supp. 275, 279 n.5 (W .D. Va. 1995); U nited Transp. U nion v. Springfield Terminal R y. Co., 132 F.R.D. 4 (D. M aine 1990); Springfield Terminal R y. Co. v. U nited Transp. U nion, M isc. N o. 89-0073, 1989 U.S. D ist. LEXIS 5478 (D.D.C. M ay 18, 1989); Shape of Things to Come, Inc. v. County of Kane, 588 F. Supp. 1192 (N.D. III. 1984); B ardoff v. U nited States, 628 A .2d 86 (D.C. 1993). 
way that buffered members and staff against prosecutors, ${ }^{63}$ as in the lengthy proceedings for R epresentative M CD ade. ${ }^{64}$ The Senate $L$ egal Counsel has been less forward about providing members and staff with such buffering. ${ }^{65} \mathrm{M}$ y sixteen-year service in the two offices and my countless discussions with other counsel in both offices have led me to develop only a theory, not a confident understanding, of the difference. ${ }^{66}$ I think of it in terms of a difference between the cultures of the two chambers. The H ouse culture defers less to prosecutors, seeing their power frequently and potently employed, knowing there is no necessary correlation between the H ouse's own internal judgments upon members and the diverse calculations of the ninety-plus politically appointed U .S. A ttorneys around the country, and hence sometimes distrusting prosecutors' motivations and judgments. ${ }^{67}$ Therefore, the House culture has approved, at least at times, General Counsels who scrap with prosecutors on members' behalf. Senators have a reduced sense of vulnerability to, and distrust of, prosecutors. ${ }^{68}$ H ence, the Senate culture approves a Senate L egal Counsel who remains aloof from the controversies surrounding the occasional prosecutorial activity. B oth cultures, on the other hand, are equally sensitized to, and fed up with, the mas-

63. B esides previously cited cases, others had issues covering the gamut from the official nature of M embers' telephone calls, see In re G rand J ury I nvestigation, 587 F.2d 589 (3d Cir. 1978); U nited States v. E ilberg, 553 F. Supp. 1 (D.D.C. 1981); U nited States v. E ilberg, 507 F. Supp. 267 (E .D. Pa. 1980), to undue subjection of $\mathrm{M}$ embers to retrials and their freedom from gag orders inhibiting communication with constituents, see U nited States v. Ford, 830 F.2d 596 (6th Cir. 1987); Susan B. Glasser, H ill L eadership Intervenes in Rep. Ford's Fraud Case, R o L L CA LL, M ay 2, 1991.

64. Recently, the House General Counsel completed many effective years of presenting the House's institutional interest during the investigation, pre-trial proceedings, and trial ending with acquittal in 1995, for R epresentative M cD ade ( $R-P a$.). See U nited States V. M CD ade, N o. 96-1508 (3d Cir. J uly 12, 1996) (unpublished order), vacating N o. 92-249 (E.D. Pa. J une 5, 1996); U nited States v. M CD ade, 85 F.3d 613 (3d Cir. 1996) (table); U nited States v. M cD ade, 28 F.3d 283 (3d Cir. 1994). For an account, see M atthew R. W alker, Comment, Constitutional L aw-N arrowing the Scope of Speech or D ebate Clause Immunity-U nited States V. M CD ade, 68 TEM P. L. R EV. 377 (1995). Similarly, without raising any partisan dispute, the House General Counsel's office represented Speaker Gingrich in the wrongful discharge and defamation case filed by former House Historian Christina J effrey. See A my Keller \& J uliet Eilperin, Fired H ouse Historian Files \$16 M illion L awsuit A gainst Speaker, H is Aide, and Three D emocrats, R OLL CA LL, M ay 16, 1996.

65. This is a matter of proportion, not complete Senate avoidance of criminal cases. D uring the grand jury investigation of Senator D avid D urenberger ( $R-M$ inn.), questions arose as to whether D OJ had infringed the Senator's Speech or D ebate protections. U pon indictment, the Senate L egal Counsel did appear and file an amicus brief in support of Senator D urenberger. See U nited States v. D urenberger, Crim. N o. 3-93-65, 1993 W L 738477 (D. M inn. D ec. 3, 1993). For the case following the subsequent reindictment, see U nited States v. D urenberger, 48 F.3d 1239 (D.C. Cir. 1995).

66. It traces back to basic philosophical contrasts between the first H ouse Counsel, Stanley B rand, and the first Senate Counsel, M ichael D avidson, and yet the contrast has outlasted them both.

67. To show the very diverse manifestations of House suspicions of federal prosecutors, during the R eagan (and successor) A dministrations, there were observations that A ttorneys General had approved disproportionate numbers of black $D$ emocratic representatives for criminal investigation and prosecution. During the Bush A dministration, there were observations that the A ttorney General set up a House B ank inquiry calculated maximally to injure R epresentatives in the 1992 election. D uring the Clinton A dministration, Chairman Dan Burton ( $\mathrm{R}-\mathrm{Ind}$.) expressed suspicions about the handling of his investigation for extortion, at a time when his committee was holding hearings about the A ttorney $G$ eneral's handling of the 1996 campaign finance matter.

68. Senators are fewer in number, higher in status, having greater average age and experience, more likely to be of the same race as prosecutors, and somewhat more able to survive politically a prosecutorial inquiry due to their six-year terms and larger constituent bases. 
sive current tides of civil litigation and discovery, and so both cultures expect, and receive, counsel offices that aggressively respond to civil suits and subpoenas.

W hether the matter involves partisan interests, such as the 1995 W hitewater Subpoena, or individual interests, such as the cases of members in civil or criminal trouble, congressional counsel face the initial problem of finding an institutional interest to represent. Congressional counsel must find an interest that is distinct from some partisan or individual interest appropriation represented by majority and minority counsel on committees or in personal offices. They must serve the chamber's long-term, non partisan interest, not just seek to keep majority members in office or just promote the majority's political agenda. E ven more, congressional counsel face the problem of perceptions and appearances, namely, that regardless of how well they do at finding and hewing to an institutional interest, critics will identify them with the partisan or individual interests also present in the case. ${ }^{69}$

A s the 1995 Whitewater Subpoena matter suggests, part of the answer in finding the institutional interests consists in recognizing that congressional counsel offices do not participate in planning or deciding the activities that are typically the basis of outside lawsuits, subpoenas, or investigations. A s long as the member's activity occurs in her official capacity, she shares with all her colleagues the collective and, hence, institutional interest that official activities should receive the necessary support from official resources, including the resources for legal representation. W hatever the institution's reasons for allowing members to conduct their official and representational activities, from legislating and Washington casework to press releases and opening offices in the state or district, the institution has the same interest in providing legal representation that it has in providing office supplies, computer support, staff funding, and so forth. When the individual interest becomes very strong and the bounds of representation by government counsel loom near, as in criminal matters, then the primary representation function belongs to private counsel, with congressional counsel representing a separate institutional amicus.

As for the perception problem, the congressional counsel offices avoid many potential concerns by employing general policies about categories of cases in which they will and will not provide representation. A s previously described, the offices represent members in the defense of civil suits and evidentiary demands arising out of their official position, without regard to the party of the member or the attractiveness of the particular representation. ${ }^{70} \mathrm{O}$ the

69. What makes the dilemma of congressional counsel so acute in regard to perceptions is the intensity in the L egislative Branch of press coverage, and debate, about partisan and ethical suspicions. A rguably there is no institution in society that can match the U nited States Congress in its dedication to the critical, perhaps even hypercritically suspicious, political analysis of everything said or done therein, including legal representation. That has always been part of the job of politics, and today's W ashington climate, discussed later in the conclusion, accentuates it.

70. See 2 U.S.C. § 288c(a)(1) (1994) (Senate L egal Counsel); R ule I.11 of the House of R epresentatives ("L egal assistance and representation shall be provided without regard to political affiliation."). 
other hand, congressional counsel take no part in individual members' quests for information ${ }^{71}$ or in certain kinds of individual members' submissions as amicus curiae. ${ }^{72}$ Such categorical rules depoliticize a large portion of the representational decisions, avoiding both the reality, and the perception, of conflict in many cases. Journalistic and member comment, and debate in the chamber, routinely follow whenever the counsel offices make a representational decision open to dispute.

\section{$\mathrm{V}$ \\ CONCLUSION}

A s each office approaches its twentieth anniversary next year, they seem to be a major success. There is no sign that either chamber thinks it could receive adequate representation from hired private counsel or from DOJ, as they did before 1979.73 Moreover, the courts and DOJ accept congressional counsel as necessary presenters of a special federal government position. Today it is difficult to imagine how the Senate and House could determine their institutional interests, and present these to the legal world, without these legal offices.

Just as change in the legal environment of Congress produced the Senate and House Counsel offices, so, too, change in the Congress itself may intensify the dilemmas faced by those offices in finding the institutional interests they represent and avoiding the perception of identification with purely partisan or individual interests. N ot only is the special climate of the formative period long past, ${ }^{74}$ but the Congress of twenty years ago had several institutional-stability sources, now lacking, that mitigated internal conflicts and thereby made institutional interests more readily determinable. Political parties of that time had more overlap and more in common owing to "swing-vote" characteristics of conservative Southern Democrats and moderate Republicans. M ember and staff turnover was lower. There was more institutional loyalty, comity, and civility to balance the centrifugal forces of hardened partisanship, electronic media coverage, and massive independent campaign financing. Rapid flips in party control for the presidency and both Houses make it harder for those at

71. See Southern Christian Leadership Conf. v. Kelley, 747 F.2d 777 (D.C. Cir. 1984), aff'g Lee v. Kelley, 99 F.R.D. 340 (D.D.C. 1983).

72. The subject of M embers' amicus briefs has recently been discussed in E ric H eberlig \& R orie L. Spill, Cuing the Courts: Members of Congress as Friends of the Court (Paper for the $1997 \mathrm{~A} \mathrm{~m}$. Poli. Sci. A ss'n, A ug. 29-31, 1997) (on file with author).

73. Nor has there been any movement in the past two decades toward a unified office of Congressional L egal Counsel. It came to appear, particularly during the years 1981-86 of different party control of the two chambers, that the Counsels have their hands filled responding to the complex signals from their separate legislative institutions without the further challenge of reconciling all the chambers' differences.

74. In the formative period of 1977-80, congressional D emocrats and R epublicans had different, but harmonizing, reasons for thinking that an in-house counsel's office could represent the chamber's institutional interest much better than the traditional litigators for the whole government in D OJ: Congressional $\mathrm{D}$ emocrats had been traumatized by Watergate, and congressional R epublicans had no great trust in the J ustice D epartment of the (D emocratic) Carter A dministration. 
the political level in either branch of government to place credence in their branch's having a transcendant, stable, institutional interest.

The changed environment means more intense problems for institutional congressional counsel identifying, and gaining general agreement on, a transcendant institutional interest, but, at the same time, creates a certain urgency for them to do so. The sheer burden of legal defense costs in W ashington's current legal climate of massive investigation, scrutiny, and civil suit discovery proceedings creates a common interest in Congress for counsel offices that lift that burden off of everyone, so long as the line drawn regarding when representation will be provided, and when not, is perceived as following consistent standards. In an era of member and staff turnover, and of flips in party control, Senate and House offices that can succeed in providing both the image, and the reality, of nonpartisanship and institutional memory become even more necessary. Therefore, the Senate and House will likely continue to impose upon their counsel offices the dilemma of choosing, in the midst of contention and disputation, something that approximates an institutional interest to represent. 